\title{
Effects of Different Maturation Media on In Vitro Produced Bovine Embryos Co-Cultured with Bovine Oviduct Epithelial Cells or Cumulus Cells
}

\author{
C. Larocca' ${ }^{*}$, S. Kmaid', J. Calvo², J.E. Romano, \\ M. Viqueira ${ }^{2}$ and Osamu Dochit \\ 'Laboratorio de Transplante de Embriones y Biotécnicas, ${ }^{2}$ Departamento de Morfoloǵa y Desarrollo, \\ ${ }^{3}$ Departamento de Fisiolog ga, Facultad de Veterinaria, Lasplaces 1550, 11600 Montevideo, Uruguay and \\ ${ }^{4}$ National Livestock Breeding Center, Ministry of Agriculture, Forestry \& Fisheries, Nishi-Shirakawa-gun, \\ Fukushima 961, Japan
}

\begin{abstract}
The objective of the present experiment was to compare the effects of different maturation media on developmental capacity of in vitro fertilized bovine oocytes when co-cultured with bovine oviduct epithelial cells (BOEC) or cumulus cell monolayer (CCM). Oocytes aspirated from follicles of $2-5 \mathrm{~mm}$ in diameter were divided into 4 groups and incubated for 22-24 h. Medium for control group was TCM 199 with 10\% newborn calf serum (Control group). For the other groups, 30\% follicular fluid (FF group), $10 \%$ estrus cow serum (ECS group) or $0.02 \mathrm{AU} / \mathrm{ml}$ of $\mathrm{FSH}$ and $1 \mu \mathrm{g} / \mathrm{ml}$ of estradiol $\beta$ (FSH/E2 group) were added to $C$ group. Frozen-thawed semen treated with heparin and caffeine were used for ova insemination. Oocytes were placed on BOEC $(n=572)$ or CCM co-culture $(n=1,050)$ and cleavage rate and numbers of the stage of morula or blastocyst (morulal blastocyst stage) were recorded. The percentage of embryos cleaved were lower in ECS than in other groups $(P<0.05)(27.5 \%, 27.9 \%, 18.2 \%$ and $23.9 \%$ for FF, FSH E2, ECS and control group, respectively). Development to the morula/blastocyst stage was not different among groups (16.1 to 9.3\%). Effect of co-culture with BOEC or CCM on cleavage and developmental capacity were not different $(P>0.05)$. The proportion of morula/blastocyst from cleaved ova in FF and ECS groups were significantly higher than FSH/E2 and control groups $(P<0.01)$. Fifteen blastocyst were transferred to 15 heifers and two recipients were confirmed pregant at day 30 and 90, and finally 2 male calves were born. The production of 2 calves from in vitro matured, fertilized and
\end{abstract}

Received: September 19, 1994

Accepted: February 1, 1995

*To whom correspondence should be addressed. developed embryos was first success in Uruguay. These results indicate that certain biological fluids such as FF and ECS induce successful maturation of bovine follicular oocytes in vitro and that resulting embryos can be successfully cultured on either BOEC or CCM.

Key words: IVM, IVF, Co-culture, Cleavage rate, In vitro development.

In recent years, the success of in vitro oocyte maturation and fertilization in cattle has been greatly improved. In vitro produced (IVP) embryos have become an alternative for basic research as well as for improving genetic resources in animal breeding programs $[10,14]$. Although a wide variety of culture media have been used, a simple and economic culture system to support embryonic development beyond the morula stage is still required [8]. The use of bovine fluids that mimic physiological events during oocyte maturation, such as preovulatory follicular biological fluid (FF), estrus cow serum (ECS) or the addition of gonadotrophic and steroid hormones have been reported $[13,15-18,20]$. Alternatively, different co-culture systems such as BOEC and $\mathrm{CCM}$ have been utilized for in vitro produced IVP embryos $[3,7,12,19]$. The present experiment was carried out to compare the effects of FF, ECS or follicle stimulating hormone and estradiol- $\beta$ (FSH/E2) added to maturation medium on capacity of in vitro cleavage and development of bovine embryos co-cultured with BOEC or CCM of bovine oocytes. And the present experiment was first success of production calf from in vitro maturation, fertilized and developed embryos. 


\section{Materials and Methods}

Collection and in vitro culture of oocytes: Ovaries were obtained from a local slaughter-house and transported to the laboratory at $30-35{ }^{\circ} \mathrm{C}$ in physiological saline solution $(0.9 \%)$ with $100 \mu \mathrm{g} / \mathrm{ml}$ Gentamicine (Gentamicine. Laboratories Herix S.A., Montevideo. Uruguay) within $3 \mathrm{~h}$ of collection. Surface follicles (2-5 mm in diameter) were punctured with an $18 \mathrm{G}$ hypodermic needle connected to a $5 \mathrm{ml}$ syringe. Only oocytes with compact cumulus cells were used. These oocytes were washed 3 times with aspiration medium Dulbecco PBS (PBS. Gibco Laboratories, Grand Island, NY, U.S.A.) with $1 \mathrm{mg} / \mathrm{ml}$ glucose and $36 \mathrm{mg} / \mathrm{l}$ sodium pyruvate supplemented with $10 \%$ Newborn Calf Serum (NCS, Gibco Laboratories. Grand Island, NY, U.S.A.) and 100 IU/ml Penicillin (Sigma Chemical Co., St. Louis, MO, U.S.A) and $100 \mu \mathrm{g} / \mathrm{m}$ Streptomycin (Sigma Chemical Co., St. Louis, MO, U.S.A.)(PBS-NCS). For maturation, oocytes were washed twice in $25 \mathrm{mM}$ Hepes buffered TCM 199 with Earle's Salts (TCM-199. Gibco Laboratories. Grand Island, NY, U.S.A.) supplemented with 0.25 $\mathrm{mM}$ of sodium pyruvate, $10 \% \mathrm{NCS}, 100 \mathrm{lU} / \mathrm{ml}$ Penicillin (Sigma Chemical Co. St. Louis, MO, U.S.A.) and 100 $\mu \mathrm{g} / \mathrm{ml}$ Streptomycin (Sigma Chemical Co. St. Louis, MO, U.S.A) (TCM-NCS). Oocytes were cultured for 22-24 h in $500 \mu$ of the following media: 1) $30 \%(\mathrm{v} / \mathrm{v})$ follicular fluid was added to TCM-NCS (FF, $n=421$ ); 2) $0.02 \mathrm{AU} /$ $\mathrm{ml}$ Follicle Stimulating Hormone (Antrin. Denka, Japan) and $1 \mu \mathrm{g} / \mathrm{ml}$ of estradiol- $\beta$ (Estradiol- $\beta$, Sigma Chemical Co. St. Louis, U.S.A.) were added to TCM-NCS (FSH/ $E 2, n=410$ ); 3) $10 \%$ estrus cow serum was added to TCM-NCS(ECS, $n=373$ ); 4) TCM-NCS (Control, $n=418$ ). The follicular fluid from a large follicles $(>15 \mathrm{~mm})$ was aspirated aseptically from ovaries with regressing corpus luteum. After centrifuged $(400 \mathrm{~g}, 10 \mathrm{~min})$ follicular fluid and ECS were heat inactivated at $56^{\circ} \mathrm{C}$ for $30 \mathrm{~min}$. For each maturation group 70 to 100 oocytes were cultured in $500 \mu$ drop for each treatment and were then covered with paraffin oil (Paraffin oil. E.R. Squibb \& Sons, Inc. Princeton, NJ, U.S.A.). Five replicates were evaluated for each media and the groups were maintained throughout the experiment. All incubations were conducted at $38.5^{\circ} \mathrm{C}$ in $99 \%$ relative humidity and $5 \%$ $\mathrm{CO}_{2}$ in air.

Preparation of BOEC: The oviducts were collected at a local slaughter-house and brought in an insulated container at $5{ }^{\circ} \mathrm{C}$ to the laboratory. They were selected from reproductive tracts containing ovaries with a corpus haemorragicum. For each experimental replicate a single oviduct was dissected free of connective tissue and placed in a $90 \mathrm{~mm}$ petri dish. The fimbriae were removed, and the oviduct was grasped with a forceps and scraped gently toward the infundibulum with a sterile microscope slide. The oviductal tissue pressed out of the oviduct was transferred to a capped test tube with PBS-NCE. Tissue was then washed 2 changes of PBS-NCS and twice again with base TCM 199. Washed oviductal tissue was suspended in TCM 199 to a ratio of $1: 10(\mathrm{v} / \mathrm{v})$ then placed in a $25 \mathrm{ml}$ tissue culture flask and cultured for $24 \mathrm{~h}$. After cultured, oviductal tissue were mixed by gentle pipetting and $50 \mu$ of the suspension were added to each $500 \mu$ drop of base TCM 199 culture medium for subsequent culture of zygotes. A mixed oviductal population of ciliated vesicles and monolayer developed over time.

Preparation of CCM: Follicular fluid of $2-5 \mathrm{~mm}$ follicles was aspirated and transferred to a $90 \mathrm{~mm}$ petri dish. Oocyte cumulus cells complexes were picked up from the dish, washed three times PBS-NCS with $10 \%$ NCS and twice with TCM-NCS. The oocytes of these complexes were aspirated with a small bore pasteur pipette and discarded. Approximately 20 clumps of cumulus cells were placed in $500 \mu \mathrm{l}$ drops of TCM-NCS covered with paraffin oil. Cumulus cells attached to the bottom of the culture dish and formed a monolayer after 72-96 h. Zygotes were cultured on this monolayer.

Semen preparation: Frozen semen from a single ejaculate of a Holstein bull of proven fertility was used. For each insemination 3 straws were thawed in water at $37{ }^{\circ} \mathrm{C}$ for $20 \mathrm{sec}$, washed twice and centrifuged at 500 $\mathrm{g}$ for $5 \mathrm{~min}$ with modified Brackett and Oliphant medium (BO)[4] without glucose and bovine serum albumin (BSA). BO medium was supplemented with $3.884 \mathrm{mg} /$ $\mathrm{ml}$ caffeine (Caffeine sodium benzoate, Sigma Chemical, St. Louis, MO, U.S.A.) and $0.02 \mathrm{mg} / \mathrm{ml}$ heparin (Heparine. Sigma Chemical, St. Louis, MO, U.S.A.). Semen concentration was adjusted to 12.5 millions spermatozoa/ml using BO dilution medium containing $20 \mathrm{mg} /$ $\mathrm{ml}$ of BSA (Fraction V, Sigma Chemical, St. Louis, MO, U.S.A.) without heparin and caffeine. Insemination drops of $100 \mu \mathrm{l}$ were prepared with this sperm suspension, with a final concentration of $1.944 \mathrm{mg} / \mathrm{ml}$ caffeine, 0.01 $\mathrm{mg} / \mathrm{ml}$ heparin and $10 \mathrm{mg} / \mathrm{ml} \mathrm{BSA}$, covered with paraffin oil.

Insemination and culture: Incubated oocytes were taken out of maturation drops, washed in $\mathrm{BO}$ medium containing $10 \mathrm{mg} / \mathrm{ml} \mathrm{BSA}$ and transferred to insemination drops (20 to 25 oocytes/drop) with a minimum amount of medium and incubated for $5 \mathrm{~h}$. After insemination, ova were washed twice in TCM-NCE and 
transferred to each development medium. Development medium was replaced every $48 \mathrm{~h}$. Observations at $48 \mathrm{~h}$ for cleavage rate and every $24 \mathrm{~h}$ up to day 9 for morula and blastocyst development were made.

Embryo transfer to recipient animal: Fifteen embryos that developed into blastocyst were transferred non-surgically ( $n=13$, from FSH/E2 group) or surgically ( $n=2$, from FF group) to the uteri of heifers at day 7 or 8 (day $0=$ estrus) of the cycle. Pregnancy diagnosis was done by ultrasound at day 30 and rectal palpation at day 90 .

Statistical analysis and experimental design: Experimental design was a $4 \times 2$ factorial ( 4 different maturation media and 2 different co-culture conditions). Cleavage rate was calculated as a percentage of no of cleaved from inseminated oocytes. Mean proportions of oocytes cleaving and developing to morula/blastocyst stage (from inseminated oocytes and from cleaved ova) were compared by analysis of variance. Influence of maturation medium, co-culture system and their interaction were also tested by analysis of variance [21].

\section{Results}

Rates of cleavage and embryos developed to morula/ blastocyst stages results for each medium in different co-culture system are summarized in Table 1 . The cleavage rate for $\mathrm{FF}, \mathrm{FSH} / \mathrm{E} 2$, ECS and control were $27.5 \%$, $27.9 \%, 18.2 \%$ and $23.9 \%$ (mean SEM), respectively. The average of cleavage rate was higher for FF, FSH/ E3 and control groups when compared with ECS group $(P<0.05)$. Cleavage rate was low for all groups. The cleavage rate for BOEC and CCM co-cultures was $22.2 \pm 2.3 \%$ and $25.9 \pm 1.8 \%$ (mean SEM), respectively. There was no significant interaction between maturation medium type and co-culture system.

The greatest proportion of embryos to reach the morula/blastocyst stage was achieved with $30 \%$ of FF in co-culture with CCM. However, development to morula/blastocyst were not different among maturation groups and co-culture systems (BOEC: $12.6 \%$ and CCM: $10.9 \%, P>0.05)$. In spite of a low cleavage rate for all treatments, $9.3 \%$ to $16.1 \%$ of inceminated ova developed to morula/blastocyst stage. The proportion of morula/blastocyst from cleaved ova in FF and ECS groups were significantly higher than FSH/E2 and control groups (chi-square test, $P<0.01$ ).

Fifteen blastocysts were transferred to 15 heifers and two recipients were confirmed pregnant at day 30 and 90 , finally 2 male calves were born.

\section{Discussion}

Present knowledge of requirements of in vitro produced embryos is based mainly on empirical findings. Under our experimental conditions there was no difference among treatments, but in ECS and FF groups, proportion of morula/blastocyst from cleaved ova had a tendency to be higher. Oocyte maturation conditions markedly affects developmental potential of zygotes [14]. We have reported [13] the successful use of FF in oocyte culture. The addition of FF from preovulatory follicles also increase meiotic maturation and enhanced embryonic development, which we felt neutralized the poor rates of cleavage $[16,17]$. Fassi-Fihri et al. [6] found that granulosa cells from pre-ovulatory follicles enhanced the developmental rate of embryos but no definitive effect of FF was shown. The effects of hormones addition ( $\mathrm{FSH}$ and estradiol- $\beta$ ) in maturation media on subsequent development are variable. Olson et al. [15] reported lower percentages of cleaved ova that developed to morula/blastocyst using $\mathrm{FSH}$ during oocyte maturation compared to ECS. The completion

Table 1. Effect of maturation media and co-culture with BOEC or CCM and developed to morula/blastocyst of bovine oocytes matured and fertilized in vitro ${ }^{1}$

\begin{tabular}{|c|c|c|c|c|c|c|c|c|}
\hline \multirow[t]{2}{*}{ Groups } & \multicolumn{5}{|c|}{ Cleavage } & \multicolumn{3}{|c|}{ Development } \\
\hline & $\mathrm{n}$ & $\mathrm{BOEC}^{2}$ & $\mathrm{n}$ & $\mathrm{CCM}^{3}$ & mean & BOEC & $\mathrm{CCM}$ & mean \\
\hline$\overline{\mathrm{FF} 4}$ & 116 & $25.6 \pm 1.8^{\mathrm{a}}$ & 305 & $28.5 \pm 1.5^{\mathrm{a}}$ & $27.5^{\mathrm{a}}$ & $13.6 \pm 0.2^{\mathrm{a}}$ & $17.3 \pm 0.6^{\mathrm{a}}$ & $16.1^{\mathrm{a}}$ \\
\hline FSH/E25 & 178 & $25.0 \pm 1.5^{\mathrm{a}}$ & 232 & $30.8 \pm 2.1^{\mathrm{a}}$ & $27.9^{a}$ & $10.7 \pm 0.8^{a}$ & $7.7 \pm 2.3^{a}$ & $9.3^{\mathrm{a}}$ \\
\hline ECS6 & 87 & $16.3 \pm 0.7^{a}$ & 286 & $19.4 \pm 1.6^{\mathrm{a}}$ & $18.2^{\mathrm{b}}$ & $14.0 \pm 0.7^{a}$ & $11.1 \pm 0.5^{\mathrm{a}}$ & $12.3^{\mathrm{a}}$ \\
\hline Control & 191 & $21.9 \pm 2.3^{a}$ & 227 & $25.2 \pm 2.2^{\mathrm{a}}$ & $23.9^{a}$ & $12.0 \pm 1.9^{a}$ & $7.4 \pm 0.6^{\mathrm{a}}$ & $9.3^{\mathrm{a}}$ \\
\hline$\overline{\text { Mean }}$ & & $22.2 \pm 2.3$ & & $25.9 \pm 1.8$ & 24.4 & $12.6 \pm 0.9$ & $10.9 \pm 1.0$ & 11.8 \\
\hline
\end{tabular}

abDifferent superscripts in the same column were significantly different $(P<0.05)$. 1Proportions of cleavage and developed morula/blastocyst are expressed as mean values \pm SEM. ${ }^{2}$ Bovine oviduct epithelial cells. ${ }^{3}$ Cumulus cell monolayers. ${ }^{4}$ Follicular fluid. ${ }^{5}$ Follicle stimulating hormone/estradiol- $\beta$. ${ }^{6}$ Estrus cow serum. 
of meiosis was delayed with $\mathrm{FSH}$ in oocyte maturation medium [5]. The addition of E2 did not enhance developmental capacity of in vitro fertilized bovine oocytes but ECS increased cleavage and development [17]. Other researchers showed a beneficial effect of ECS on maturation, fertilization and cleavage rate of bovine oocytes $[9,18,20]$. Our results showed a positive influence of ECS only on development of cleaved ova to the morula/blastocyst stage.

The influence of co-culture system on developmental capacity of in vitro produced zygotes have been shown. Bavister [1] proposed that the cells in co-culture may act through the secretion of some beneficial factors and/or remove detrimental factors. Cells could also modify the gas environment of the embryos [8]. We, however, could not established any difference between two different co-culture cells. It is seems that efficiency of the CCM or BOEC co-culture is apparent from present experiment results. Berg and Brem [3] reported that the presence of $\mathrm{CCM}$ provided superior conditions for embryo development compared to BOEC. On the contrary Wiemer et al. [22] have obtained superior development to blastocysts with co-culture in BOEC rather than CCM. Goto et al. [11] and Behboodi et al. [2] found no differences in vitro development when they compared granulosa and oviductal cell co-cultures, although embryos co-cultured with BOEC developed faster.

The results of the present experiment showed a tendency for FF and ECS supplementation of maturation medium to increase the proportion of inseminated or cleaved oocytes reaching the morula/blastocyst stage. The addition of biological fluids such as ECS and FF can successfully replace hormones added to maturation medium. No difference between BOEC or CCM for coculture for IVP zygote to the morula/blastocyst stage of development were found. The production of 2 calves from in vitro matured, fertilized and developed embryos was first success in Uruguay.

\section{Acknowledgments}

We wish to thank Drs Reuben J. Mapletoft and Marcelo del Campo of University of Saskatchewan for reading the manuscript and suggesting valuable comments as well as Japan International Cooperation Agency. This experiment received economical support from the Comision Sectorial de Investigacion Cientffica Proyecto "Tecnicas de Impacto en Produccion Animal." from Universidad de la Republica R.O.U.

\section{References}

1. Bavister, B.D. (1988): Role of oviductal secretions in embryonic growth in vivo and in vitro. Theriogenology, $29,143-154$

2. Behboodi, E., Anderson, G.B. and BonDurant, R.H. (1992): Development of in vitro fertilized oocytes from pregnant and non-pregnant cows in oviductal epithelial and cumulus cell co-culture systems. Theriogenology, 38, 1077-1084.

3. Berg, U. and Brem, G. (1990): Developmental rates of in vitro produced IVM-IVF bovine oocytes in different cell co-culture systems. Theriogenology, 33, 195.

4. Brackett, B.G. and Oliphant, G.(1975): Capacitation of rabbit spermatozoa in vitro. Biol. Reprod., 12, 260274.

5. Dominko, T. and First, N.L. (1992): Kinetics of bovine oocyte maturation allows selection for developmental competence and is affected by gonadotropins. Theriogenology, 37, 203.

6. Fassi-Fihri, N., Chupin, D., Marquant-Leguienne, B. and Thibier, M. (1992): Critical effect of granulosa cells from preovulatory follicles on IVM, IVF and embryonic development in cattle. Theriogenology, 35, 198.

7. Fukuda, Y., Ichikawa, M., Naito, K. and Toyoda, Y. (1990): Birth of normal calves resulting from bovine oocytes matured, fertilized, and cultured with cumulus cells in vitro up to the blastocyst stage. Biol. Reprod., 42, 114-119.

8. Fukui, Y., McGowan, L.T., James, R.W., Pugh, P.A. and Tervit, H.R. (1991) : Factors affecting the in vitro development to blastocyst of bovine oocytes matured and fertilized in vitro. J. Reprod. Fert., 92, 125-131.

9. Fukui, Y. (1989): Effects of sera and steroid hormones on development of bovine oocytes matured and fertilized in vitro and co-cultured with bovine oviduct epithelial cells. J. Anim. Sci., 67, 1318-1323.

10. Gordon, I. and Lu, K.H. (1990): Production of embryos in vitro and its impact on livestock production. Theriogenology, 33, 77-87.

11. Goto, K., Iwai, N., Takuma, Y. and Nakanishi, Y. (1992): Co-culture of in vitro fertilized bovine embryos with different cell monolayers. J. Anim. Sci., 70, 1449-1453.

12. Goto, K., Kajihara, Y., Kosaka, S., Koba, M., Nakanishi, Y. and Ogawa, K. (1988): Pregnancies after co-culture of cumulus cells with bovine follicular rived from in vitro fertilization of in vitro matured follicular oocytes. J. Reprod. Fert., 83, 753-758.

13. Larocca, C., Kmaid, S. and Calvo, J. (1993): Effect of follicular fluid and estrus cow serum on maturation, fertilization and development of the bovine oocyte in vitro. Theriogenology, 39, 253.

14. Leifried-Rutledge, M.L., Critser, E.S., Parrish, J.J. and First, N.L. (1989): In vitro maturation and fertilization of bovine oocytes. Theriogenology, 31, 61-74. 
15. Olson, S.E., Romero, A., Thomas, W.K. and Seidel, G.E. Jr. (1990): Effects of FSH and Heparin on in vitro maturation fertilization and development of the bovine oocytes. Theriogenology, 33, 293.

16. Romero, A., Thomas, W.K., Olson, S.E. and Seidel, G.E. Jr. (1990): Follicular fluid obtained after the LH surge stimulates meiotic maturation of bovine oocytes. Theriogenology, 33, 310.

17. Romero, A., Olson, S.E., Thomas, W.K. and Seidel, G.E. Jr. (1991): Maturation of bovine oocytes collected after the LH surge enhances subsequent embryonic development. Biol. Reprod. Suppl., 44, 149.

18. Sanbuissho, A. and Threfall, W.R. (1985): The effects of estrus cow serum on the maturation and fertilization of the bovine follicular oocyte in vitro. Theriogenology, 23, 226.
19. Scodras, J.M., Pollard, J.W. and Betteridge, K.J. (1990): Effect of somatic cell type on bovine embryonic development in co-culture. Theriogenology, 35, 269.

20. Shellander, K., Fuhrer, F., Brackett, B.G., Korb, H. and Shelger, W. (1990): In vitro fertilization and cleavage of bovine matured in medium supplemented with estrus cow serum. Theriogenology, 33, 477-485.

21. Snedecor, G.W. and Cochran, W.G. (1967): Statistical Methods. The Iowa State University Press. Ames. IA.

22. Wiemer, K.E., Watson, A.J., Polanski, V., McKenna, A.I., Schultz, G.A. and Willadsen, S. (1991): Effects of maturation and co-culture treatments on the developmental capacity of early bovine embryos. Biol. Reprod. Suppl., 46, 97.

\title{
卵管上皮細胞または卵丘細胞との共培養による ウシ体外受精卵の作出における各種成熟培養液の影響
}

\author{
C. Larocca ${ }^{1}$, S. Kmaid ${ }^{1}$, J. Calvo ${ }^{1}$, J.E. Romano ${ }^{1}$, M.Viqueira ${ }^{1}$, 堂地 修 ${ }^{2}$ \\ 1ウルグアイ大学獣医学部, ウルグアイ, モンテビデオ \\ 2 農林水産省家畜改良センター, 福島県西白河郡西郷村 $\overline{7} 961$
}

ウシ未成熟卵子を $10 \%$ 新生子牛血清加 TCM199 を基本液 （C区）として，卵胞液を $30 \%$ (FF区)，発情牛血清を $10 \%$ (ECS区) およびFSH と estradiol-B (FSH/E2区) をそれぞ れ添加した 4 種類の培養液で成熟培養を行ない，媒精後， 卵管上皮細胞または卵丘細胞との共培養により発生培羕を 行ない, 分割率および桑実胚/胚盤胞の発生率を比較した. 媒精後 48 時間目の分割率は ECS 区が他の区より低かった が (P<0.05, FF区27.5\%,FSH/E2 区 $27.9 \%$, ECS区 $18.2 \%$ およびC区 $23.9 \%$ ），桑実胚／胚盤胞への発生率に
は差は見られなかった．また，2種の共培䁲細胞間に分割 率，采実胚／胚盤胞への発生率に差は認められなかった （P>0.05）. 発生した胚盤胞 15個を受胚牛に移植した結果, 2 頭の受胎が確認され，それぞれ正常な子牛を分婏した. この体外受精による子牛の生産はウルグアイにおける最初 の成功である.これらの結果から，FFやECSのような生 体由来の物質は成熟培養に, BOEC または CCMによる共 培養は発生培養に効果的であることを示している. キーワード : IVM, IVF, 共培養, 分割率, 体外発生. 